\title{
П. О.Аовгань,
}

аспірант 3-го року навчання, кафедра обліку та оподаткування в галузях економіки, факультет обліку та аудиту, Вінницький національний аграрний університет

ORCID ID. 0000-0001-9527-5469

DOI: $10.32702 / 2306-6792.2021 .11 .73$

\section{ОСНОВИ КААСИФІКАЦІЇ НЕОБОРОТНИХ АКТИВІВ ТА ПІАХОАИ АО ЇХ УАОСКОНААЕННЯ}

\author{
P. Dovhan, \\ Postgraduate student of 3 years of study, Department of Accounting and Taxation \\ in the fields of economics, Faculty of Accounting and Auditing, Vinnytsia National Agrarian University
}

\author{
FUNDAMENTALS OF CLASSIFICATION OF NON-CURRENT ASSETS AND APPROACHES \\ TO THEIR IMPROVEMENT
}

В умовах сучасного функціонування економіки, у зв'язку з процесами економічної інтеграції в Україні проблеми обліку необоротних активів набувають актуальності. Проте слід вказати на факт відсутності чіткого визначення категорії "необоротний активів". Аля задоволення інформаційних потреб науково-дослідних господарств щодо обліку необоротних активів визначено категорію "необоротний актив" як " нематеріальні, нематеріальні та фінансові ресурси, контрольовані підприємством у результаті минулих подій, призначені Аля реалізації чи використання протягом терміну, що більший ніж 12 місяців чи операційний цикл за умови їх використання у виробничому процесі більше одного разу". У економічній літературі виділяють матеріальні, нематеріальні та фінансові (монетарні та немонетарні) необоротні активи. Визначено, що основні засоби є найбільш поширеним видом необоротних матеріальним активів. У статті наведені критерії віднесення об'єктів до складу основних засобів. Аосліджено порядок здійснення капітальних інвестицій, наведена їх класифікація. Визначено, що обсяг капітальних інвестицій за останнє десятиліття має позитивну динаміку. У 2020 році обсяг капітальних інвестицій склав 508217 тис. грн, що втричі перевищує показник у 2010 р.

У статті розглянуто основні моменту віднесення об'єктів до складу нематеріальних об'єктів Аля цілей обліку.

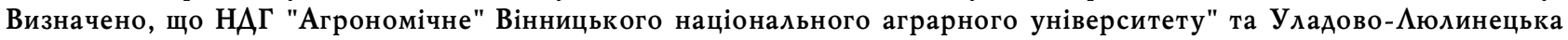
дослідно-селекційна станція - це державні установи, що займаються науковою роботою в галузі селекції та технології вирощування сільськогосподарських культур та виробництва біоенергетичної продукції. Тому Аля задоволення потреб менеджменту інформацією щодо обліку нематеріальних необоротних активів ми пропонуємо визначати вартість гудвілу. Ці господарства мають дбати про власну ділову репутацію. Піднімати рівень наукової значущості наукових розробок та виводити Україну на міжнародну арену із конкурентоспроможною продукцією.

In the current functioning of the economy, in connection with the processes of economic integration in Ukraine, the problem of accounting for non-current assets becomes relevant. However, it should be noted that there is no clear definition of the category "non-current assets". To meet the information needs of research farms on the accounting of non-current assets, the category of "non-current asset" is defined as intangible, intangible and financial resources controlled by the enterprise as a result of past events, intended for sale or use for more than $\mathbf{1 2}$ months or operating cycle provided that they are used in the production process more than once "In the economic literature there are tangible, intangible and financial (monetary and non-monetary) non-current assets. It is determined that fixed assets are the most common type of non-current tangible assets. The article presents the criteria for classifying objects as fixed assets. The order of capital investments is investigated, their classification is given. It is determined that the volume of capital investments over the last decade has a positive trend. In 2020, the volume of capital investments amounted to 508,217,000 hryvnias, which is three times more than in 2010. 
The article considers the main points of classifying objects as intangible objects for accounting purposes. It has been determined that NDG "Agronomichne" of Vinnytsia National Agrarian University and Uladovo-Liulyntsi Research and Selection Station of NAAS of Ukraine are state institutions engaged in scientific work in the field of selection and technology of cultivation of crops and production of bioenergy products.

Therefore, to meet the information management needs of accounting for intangible non-current assets, we propose to determine the value of goodwill. These farms must take care of their own business reputation. Raise the level of scientific significance of scientific developments and bring Ukraine to the international arena with competitive products.

Ключові слова: необоротні активи, класифікачія необоротних активів, бухгалтерський облік активів, основні засоби, капітальні інвестииії, гудвіл.

Key words: non-current assets, classification of non-current assets, asset accounting, fixed assets, capital investments, goodwill.

\section{ПОСТАНОВКА ПРОБЛЕМИ}

В умовах сучасного функціонування економіки України, у зв'язку з процесами економічної інтеграції в Україні проблеми обліку необоротних активів набуває актуальності. Необоротні активи відіграють важливе значення у діяльності суб'єктів господарювання всіх форм власності. Вони беруть активну участь у виробничому процесі підприємств. Під час формування основних макроекономічних показників використовуються різні рівні аналітики та показники щодо наявності та руху необоротних активів [13]. Але виникає потреба уточнення категорії "необоротні активи" як об'єкти бухгалтерського обліку у науково-дослідних господарствах, а також підходи до їх класифікації. Тож питання є актуальними, а тому потребує подальшого дослідження.

\section{АНАЛІЗ ОСТАННІХ ДОСЛІДЖЕНЬ І ПУБЛІКАЦІЙ}

Аналіз останніх досліджень і публікацій показав, що ефективність формування і використання ресурсного потенціалу у сільськогосподарських підприємствах, його вплив на фінансові результати господарської діяльності та ефективність виробництва сільськогосподарської продукції описали Гончарук I.В., Браніцький Ю.Ю., Томашук I.В. [2]. Основам класифікації та обліку необоротних активів приділяли увагу і присвятили свої праці такі науковці: Гавриловський О.С. [1], Гудзь Н.В. [3], Майорова Т.В., Крук В.В., Шевчук Я.В. [6], Семйон В.С. [13; 14], Сук А.К., Сук П.А. [15], Хорунжак Н.М., Рогожкіна В.В. [16]. У роботах даних авторів започатковано розв'язання проблеми, їх напрацювання стали основою для написання цієї статті.

\section{META CTATTI}

Аослідити визначення поняття "необоротні активи" як об'єкти бухгалтерського обліку у науково-дослідних господарствах, уточнити склад та класифікацію необоротних активів.

\section{ВИКЛАД ОСНОВНОГО МАТЕРІАЛУ ДОСЛІДЖЕННЯ}

Науково-дослідні господарства відіграють важливу роль у розширенні кола наукових знань, відпрацювання теоретичних розробок на практиці та формування потенціалу для розвитку окремих галузей економіки України.

На Вінниччині функціонує ряд провідних науково-дослідних господарств, серед них НАГ "Агрономічне" Вінницького національного аг-

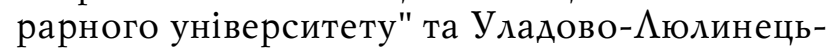
ка дослідно-селекційна станція, що входить до структури Інституту біоенергетичних культур і цукрових буряків. Ці установи створені з метою організаційно-господарського забезпечення умов для проведення фундаментальних та прикладних досліджень в галузі рослинництва, здійснення науково-дослідних робіт, проведення досліджень, випробувань і доопрацювання наукових розробок, їх апробації, проведення виробничої перевірки і впровадження їх у виробництво та іншої господарської діяльності [2]. Аля задоволення інформаційних потреб цих господарських структур щодо обліку необоротних активів як бухгалтерського так i управлінського визначимо категорію "актив" та "необоротний актив".

Згідно із Законом України "Про бухгалтерський облік та фінансову звітність в $\mathrm{У}_{\text {к- }}$ раїні", активи - ресурси, контрольовані підприємством у результаті минулих подій, ви- 
користання яких, як очікується, приведе до отримання економічних вигод у майбутньому.

У Національному положенні (стандарті) бухгалтерського обліку 1 "Загальні вимоги до фінансової звітності" вказано, що необоротні активи - всі активи, що не є оборотними. У свою чергу оборотні активи - гроші та їх еквіваленти, що не обмежені у використанні, а також інші активи, призначені для реалізації чи використання протягом операційного циклу чи протягом дванадцяти місяців з дати балансу.

Гудзь Н. В. наводить таке визначення необоротних активів - "це матеріальні, нематеріальні та фінансові ресурси, призначені для реалізації чи використання протягом терміну, що більший ніж 12 місяців чи операційний цикл" [3]. Автор наводить ряд критерій щодо визнання необоротних активів, вказуючи, що ці критерії використовуються для визнання будь-яких інших активів:

- існує імовірність того, що підприємство отримає в майбутньому економічні вигоди, пов'язані з використанням об'єкта: у виробництві товарів чи наданні послуг, призначених для реалізації підприємством; для обміну на інші активи; Аля погашення заборгованості; для поділу між власниками;

— його вартість може буди достовірно визначена [3].

На нашу думку, основним критерієм визначення складової "необоротний" $є$ саме строк корисного використання активу, що випливає із визначення категорії "основні засоби", наведеного у Національному положенні (стандарті) бухгалтерського обліку 7 "Основні засоби". Отже, основні засоби - матеріальні активи, які підприємство/установа утримує з метою використання їх у процесі виробництва/діяльності або постачання товарів, надання послуг, здавання в оренду іншим особам або для здійснення адміністративних і соціально-культурних функцій, очікуваний строк корисного використання (експлуатації) яких більше одного року (або операційного циклу, якщо він довший за рік). Згідно із нормами цього ж положення, строк корисного використання (експлуатації) очікуваний період часу, протягом якого необоротні активи будуть використовуватися підприємством/установою або з їх використанням буде виготовлено (виконано) очікуваний підприємством/установою обсяг продукції (робіт, послуг) [7].

Також варто зазначити, що критерієм для віднесення активу до складу необоротних $є$ те, що вказані активи неодноразово беруть участь у процесі виробництва.
Отже, в економічній літературі [3] виділяють матеріальні, нематеріальні та фінансові (монетарні та немонетарні) необоротні активи.

Матеріальні необоротні активи - це активи, які мають матеріальну форму, наприклад, основні засоби, інші необоротні матеріальні активи, незавершені капітальні інвестиції в матеріальні активи, довгострокові біологічні активи.

Нематеріальні активи - це немонетарні активи, які не мають матеріальної форми, сутність яких полягає у володінні правами на об'єкти інтелектуальної власності, а також інші інтелектуальні права, визнані в порядку, встановленому відповідним законодавством, об'єктом права власності особи, можуть бути ідентифіковані (ототожнені) й утримуються підприємством 3 метою використання протягом періоду, який більший за рік (або один операційний цикл, якщо він більший за рік) для виробництва, торгівлі та в адміністративних цілях або надання в оренду іншим особам.

Фінансові необоротні активи - це довгострокові фінансові інвестиції, відстрочені податкові активи, довгострокова дебіторська заборгованість.Ао монетарних активів відносять кошти та їх еквіваленти, інші активи, які мають бути отримані у фіксованій або визначеній сумі грошей - дебіторська заборгованість. Інші активи є немонетарними [3].

Отже, на нашу думку, досліджувану категорію можна визначити як "необоротні активи — це нематеріальні, нематеріальні та фінансові ресурси, контрольовані підприємством у результаті минулих подій, призначені для реалізації чи використання протягом терміну, що більший ніж 12 місяців чи операційний цикл за умови їх використання у виробничому процесі більше одного разу".

Основні засоби є найбільш поширеним видом необоротних активів. Це пояснює значну увагу науковців до цієї категорії. Аосліджуються окремо проблеми обліку операцій надходження та вибуття основних засобів, амортизаційна політика, оцінка та переоцінка, комп'ютеризація обліку та облік основних засобів у різних галузях економіки, в тому числі у бюджетних установах [13].

Оскільки науково-дослідні підприємства $€$ бюджетними організаціями, то облік на даних господарствах здійснюється згідно чинного законодавства з використанням національних стандартів бухгалтерського обліку в державному секторі та Плану рахунків у державному секторі. Нормами Національного положення (стандарту) бухгалтерського обліку в держав- 
ному секторі 121 "Основні засоби" визначено, що основні засоби - матеріальні активи, які утримуються для використання їх у виробництві/діяльності або при постачанні товарів, виконанні робіт і наданні послуг для досягнення поставленої мети та/або задоволення потреб суб'єкта державного сектору або здавання в оренду іншим особам і використовуються, за очікуванням, більше одного року [9].

Одиницею обліку основних засобів $€$ об'єкт основних засобів, а саме:

1) закінчений пристрій з усіма пристосуваннями і приладдям до нього;

2) конструктивно відокремлений предмет, призначений для виконання певних самостійних функцій;

3) відокремлений комплекс конструктивно з'єднаних предметів однакового або різного призначення, що мають для їх обслуговування загальні пристосування, приладдя, керування та єдиний фундамент, унаслідок чого кожен предмет може виконувати свої функції, а комплекс - певну роботу тільки в складі комплексу, а не самостійно;

4) інший актив, що відповідає визначенню основних засобів, або частина такого активу, що контролюється суб'єктом державного сектору.

Якщо один об'єкт основних засобів складається з частин, які мають різний строк корисного використання (експлуатації), то кожна 3 цих частин може визнаватися в бухгалтерському обліку як окремий об'єкт основних засобів.

Об'єкт основних засобів визнається активом, коли існує ймовірність отримання суб'єктом державного сектору майбутніх економічних вигід, пов'язаних з його використанням, та/ або він має потенціал корисності для суспільства; і вартість об'єкта основних засобів може бути визначена.

Основні засоби класифікуються за такими групами:

1. Основні засоби, до яких включаються:

- земельні ділянки;

- капітальні витрати на поліпшення земель;

- будинки, споруди та передавальні пристрої;

- машини та обладнання;

— транспортні засоби;

- інструменти, прилади, інвентар;

- тварини, багаторічні насадження та плодоносні рослини;

- інші основні засоби [9].

2. Інші необоротні матеріальні активи включають:

- музейні фонд;
— бібліотечні фонди;

- малоцінні необоротні матеріальні активи;

— білизну, постільні речі, одяг та взуття;

- природні ресурси;

— інвентарну тару;

- необоротні матеріальні активи спеціального призначення;

- інші необоротні матеріальні активи.

Законом України від 16.01.2020 р. № 466-IX "Про внесення змін до Податкового кодексу України щодо вдосконалення адміністрування податків, усунення технічних та логічних неузгодженостей у податковому законодавстві" 3 23 травня 2020 року змінено вартісний критерій визначення основних засобів 36 до 20 тис. гривень. Цей критерій застосовується до основних засобів, що вводяться в експлуатацію після 22 травня 2020 року. Основні засоби введені в експлуатацію до 23 травня 2020 року продовжують амортизуватись у обліку як основні засоби, навіть якщо їх залишкова балансова вартість не перевищує 20 тис. гривень [11].

Об'єкт основних засобів оцінюється за первісною вартістю, якою є:

1) вартість придбання у разі придбання за плату;

2) собівартість виробництва у разі самостійного виготовлення (створення);

3) справедлива вартість у разі отримання без оплати від фізичних та юридичних осіб (крім суб'єктів державного сектору);

4) первісна (переоцінена) вартість основних засобів у разі отримання без оплати від суб'єктів державного сектору;

5) залишкова вартість переданого об'єкта основних засобів у разі отримання у результаті обміну на інший актив;

6) умовна вартість у разі відсутності активного ринку [9].

Варто зазначити, що первісна вартість об'єкта основних засобів у разі придбання за плату складається 3 таких витрат: суми, що сплачують постачальникам активів та підрядникам за виконання будівельно-монтажних робіт (без непрямих податків); реєстраційні збори, державне мито та аналогічні платежі, що здійснюються у зв'язку з придбанням (отриманням) прав на об'єкт основних засобів; суми ввізного мита; суми непрямих податків у зв'язку з придбанням (створенням) основних засобів (якщо вони не відшкодовуються суб'єктові державного сектору); витрати зі страхування ризиків доставки основних засобів; витрати на транспортування, установку, монтаж, налагодження основних засобів; інші витрати, безпо- 


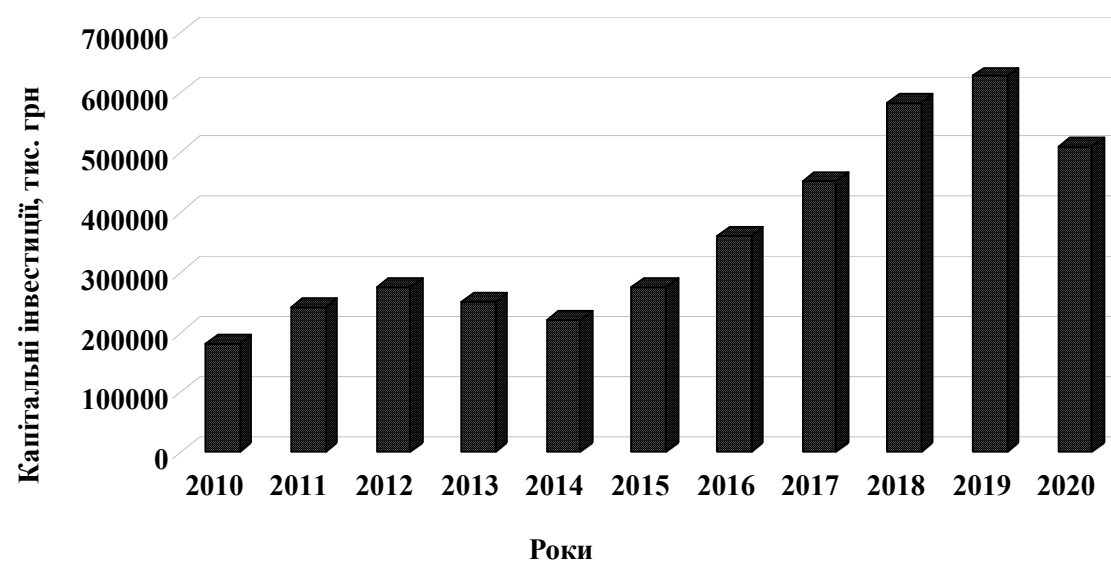

Рис. 1. Динаміка обсягу капітальних інвестицій за 2010-2020 роки, тис. грн

Ажерело: сформовано автором на основі [5].

середньо пов'язані з доведенням основних засобів до стану, у якому вони придатні для використання із запланованою метою. Фінансові витрати не включаються до первісної вартості основних засобів, придбаних (створених) повністю або частково за рахунок запозичень (за винятком фінансових витрат, які включаються до собівартості кваліфікаційних активів відповідно до національних положень (стандартів) бухгалтерського обліку в державному секторі) [9].

Порядку здійснення обліку капітальних інвестицій приділили свою увагу Майорова Т.В., Крук В.В., Шевчук Я.В. У своїй праці, проаналізувавши сутнісну характеристику капітальних інвестицій та визначивши їх основні види та форми, науковці запропонувати авторське визначення поняття капітальні інвестиції-це вкладення інвестиційних ресурсів у створення, придбання або модернізацію матеріальних та нематеріальних активів суб'єктів господарювання [6].
Згідно з НП(С)БО 7 "Основні засоби", капітальні інвестиції в необоротні матеріальні активи - витрати на будівництво, реконструкцію, модернізацію (інші поліпшення, що збільшують первісну (переоцінену) вартість), виготовлення, придбання об'єктів матеріальних необоротних активів (у тому числі необоротних матеріальних активів, призначених Аля заміни діючих, і устаткування для монтажу), що здійснюються підприємством.

За даними Аержстату України, визначено, що обсяг капітальних інвестицій за останнє десятиліття має позитивну динаміку. У 2020 році обсяг капітальних інвестицій склав 508217 тис. грн, що втричі перевищує показник на початку досліджуваного періоду (рис. 1).

Основну частину капітальних інвестицій складають інвестиції саме у матеріальні необоротні активи, а саме у машини обладнання інвентар. Обсяг капітальних інвестицій у вказані об'єкти у 2020 році склав 16636,6 тис. грн (рис. 2).

Водночас процес залучення капітальних інвестицій в економіку України суттєво загальмований впливом політичної та економічної криз останніх років. Унаслідок цього активізувались інфляційні процеси, знизився інвестиційний потенціал державного бюджету, погіршився фінансовий стан підприємств, зріс відплив банківських депозитів, збільшилась кількість збиткових фінансово-кредитних установ, скоротились обсяги банківського кредитування підприємств, знизилась інвестиційна

\footnotetext{
Програмне забезпечення та бази даних Права на комерційні позначення Інші матеріальні активи Довгострокові біологічні активи
} Земля Транспортні засоби

Машини, обладнання та інвентар Інженерні споруди Будівлі нежитлові Будівлі житлові $\begin{array}{lllll}0,0 & 50000,0 & 100000,0 & 150000,0 & 200000,0\end{array}$

Рис. 2. Капітальні інвестиції за видами активів у 2020 році, тис. грн 
активність іноземних інвесторів. Чималою мірою вповільнення інвестиційного процесу в Україні зумовлене корупцією органів державної влади, потужним податковим тягарем та недосконалою законодавчою базою, насамперед у сфері захисту прав інвесторів [6].

У "Звіті про капітальні інвестиції, вибуття й амортизацію активів" за формою № 2-інвестиції (річна), що затверджена наказом Аержстату 21.07.2017 № 195 передбачено розподіл капітальних інвестицій за видами активів та розподіл капітальних інвестицій за джерелами фінансування. Результати класифікації капітальних інвестицій згруповано у таблиці 1.

Аіяльність науково-дослідних господарства проводиться із залученням нематеріальних активів. Згідно із нормами Національного положення (стандарту) бухгалтерського обліку в державному секторі 122 "Нематеріальні активи" нематеріальний актив визнається активом, якщо його можна ідентифікувати (може бути виділений чи відокремлений від інших активів) та існує ймовірність отримання суб'єктом державного сектору майбутніх економічних вигід, пов'язаних 3 його використанням, та/або якщо він має потенціал корисності і його вартість може бути достовірно визначена [10].

Аля цілей бухгалтерського обліку нематеріальні активи включають:

1) авторське та суміжні з ним права (право на літературні, художні, музичні твори, комп'ютерні програми, програми для електроннообчислювальних машин, компіляції даних (бази даних), виконання, фонограми, відеограми, передачі (програми) організацій мовлення тощо);

2) права користування природними ресурсами (право користування надрами, іншими ресурсами природного середовища, геологічною та іншою інформацією про природне середовище тощо);

3) права на знаки для товарів і послуг (товарні знаки, торгові марки, фірмові найменування тощо);
Таблиця 1. Класифікація капітальних інвестицій

\begin{tabular}{l} 
Характеристика \\
\hline Будівлі житлові \\
\hline н них житлові будівлі, що будуються з метою \\
подальшого продажу (передачі) \\
\hline Будівлі нежитлові \\
\hline Інженерні споруди \\
\hline Машини, обладнання та інвентар \\
\hline 3 них електричне й електронне устаткування \\
\hline Транспортні засоби \\
\hline Земля \\
\hline Довгострокові біологічні активи рослинництва \\
\hline Довгострокові біологічні активи тваринництва \\
\hline Інші матеріальні активи \\
\hline Обладнання, що забезпечує функціонування \\
будівель та інженерних споруд \\
\hline Права користування природними \\
Ресурсами та майном \\
\hline З них права користування земельною ділянкою \\
\hline Права на комерційні позначення, об'єкти \\
промислової власності, авторські та суміжні права, \\
патенти, ліцензії, концесії тощо \\
\hline Програмне забезпечення та бази даних \\
\hline Витрати на розвідування корисних копалин \\
\hline Оплата послуг юристів, оцінювачів, агентів з \\
нерухомості тощо, які пов'язані з передачею прав \\
власності на невироблені активи \\
\hline Розважальні програми й оригінали літературних і \\
художніх творів \\
\hline Кошти державного бюджету \\
\hline Кошти місцевих бюджетів (міста, району, області \\
тощо) \\
\hline Власні кошти підприємств і організацій \\
\hline з них амортизаційні відрахування \\
\hline Кредити банків та інші позики \\
\hline з них кредити іноземних банків \\
Кошти інвестиційних компаній, фондів тощо \\
\hline Кошти іноземних інвесторів \\
\hline Кошти населення на будівництво житла \\
\hline Інші джерела фінансування \\
\hline
\end{tabular}

Кошти населення на будівництво житл

Інші джерела фінансування

4) права користування майном (право користування земельною ділянкою, крім права постійного користування земельною ділянкою, право користування будівлею, право на оренду приміщень тощо);

5) права на об'єкти промислової власності (право на винаходи, розробки, корисні моделі, промислові зразки, сорти рослин, породи тварин, захист від недобросовісної конкуренції тощо);

6) інші нематеріальні активи (право на провадження діяльності, використання економічних та інших привілеїв тощо) [10].

Нематеріальний актив, який виникає в результаті розробок (чи на етапі розробок внутрішнього проекту), визнається активом за умов, якщо суб'єкт державного сектору має: намір, технічну можливість та ресурси для доведення нематеріального активу до стану, у якому він придатний для реалізації або використання; можливість отримання майбутніх економічних вигід або потенціалу корисності від реалізації 
або використання нематеріального активу; інформацію для достовірного визначення витрат, пов'язаних із розробкою нематеріального активу.

Об'єкт нематеріальних активів оцінюється за первісною вартістю, якою є: вартість придбання у разі придбання за плату; собівартість виробництва у разі самостійного виготовлення (створення); справедлива вартість у разі отримання без оплати від фізичних та юридичних осіб (крім суб'єктів державного сектору); первісна (переоцінена) вартість нематеріальних активів у разі отримання без оплати від суб'єктів державного сектору; залишкова вартість переданого нематеріального активу у разі отримання в результаті обміну на інший актив [10].

Первісна вартість придбаного нематеріального активу складається з ціни (вартості) придбання (крім отриманих торговельних знижок), мита, непрямих податків, що не підлягають відшкодуванню, та інших витрат, безпосередньо пов'язаних з його придбанням та доведенням до стану, у якому він придатний для використання за призначенням.

Фінансові витрати не включаються до первісної вартості нематеріальних активів, придбаних (створених) повністю або частково за рахунок запозичень (за винятком фінансових витрат, які включаються до собівартості кваліфікаційних активів відповідно до національних положень (стандартів) бухгалтерського обліку у державному секторі) [10].

Згідно пп. 138.3.4 Податкового Кодексу України нематеріальні активи теж розділено на шість груп:

група 1 - права користування природними ресурсами (право користування надрами, іншими ресурсами природного середовища, геологічною та іншою інформацією про природне середовище) (строк дії права користування відповідно до правовстановдюючого документа);

група 2 - права користування майном (право користування земельною ділянкою, крім права постійного користування земельною ділянкою відповідно до закону, право користування будівлею, право на оренду приміщень тощо) (строк дії права користування - відповідно до правовстановлюючого документа);

група 3 - права на комерційні позначення (права на торговельні марки (знаки для товарів і послуг), комерційні (фірмові) найменування тощо), крім тих, витрати на придбання яких визнаються роялті (строк дії права користування - відповідно до правовстановлюючого документа); група 4 - права на об'єкти промислової власності (право на винаходи, корисні моделі, промислові зразки, сорти рослин, породи тварин, компонування (топографії) інтегральних мікросхем, комерційні таємниці, в тому числі ноу-хау, захист від недобросовісної конкуренції тощо), крім тих, витрати на придбання яких визнаються роялті (строк дії права користування - відповідно до правовстановлюючого документа, але не менш як 5 років);

група 5 - авторське право та суміжні з ним права (право на літературні, художні, музичні твори, комп'ютерні програми, програми для електронно-обчислювальних машин, компіляції даних (баз даних), фонограми, відеограми, передач (програми) організацій мовлення тощо), крім тих, витрати на придбання яких визнаються роялті (строк дії права користування - відповідно до правовстановлюючого документа, але не менш як 2 роки);

група 6 - інші нематеріальні активи (право на ведення діяльності, використання економічних та інших привілеїв тощо) (строк дії права користування - відповідно до правовстановлюючого документа).

Якщо відповідно до правовстановлюючого документа строк дії права користування нематеріального активу не встановлено, такий строк корисного використання визначається платником податку самостійно, але не може становити менше двох та більше 10 років.

Останнім часом в Україні набула популярності практика щодо укладання угод з придбання та злиття підприємств. Водночас відображення цих процесів в обліку пов'язане з виникненням такого об'єкта обліку, як гудвіл. Особливістю гудвілу є те, що він набуває ознак активу $з$ можливістю його достовірної оцінки лише в разі придбання підприємства як цілісного майнового комплексу. Проте він створюється всередині підприємства впродовж багатьох років на основі знань, зв'язків, сучасних інформаційних, виробничих і збутових технологій та інших чинників його майбутніх конкурентних переваг [12].

E такі визначення гудвілу:

1. Гудвіл - активи, капітал фірми, який не піддається матеріальному вимірюванню (репутація, технічна компетенція, зв'язки, вплив.

2. Гудвіл - це передусім громадська думка про назву, стиль, товарний знак, логотип, проекти, товари і будь-які інші предмети, що знаходяться у власності або під контролем компанії, а також взаємовідносини з клієнтами і замовниками [12]. 
А.К. Сук класифікує нематеріальні активи на:

- торгові марки;

- заголовки та назви видань;

— комп'ютерне програмне забезпечення;

- ліцензії та привілеї;

- авторські права, патенти та інші права на промислову власність, права на обслуговування та експлуатацію;

- рецепти, формули, моделі, проекти та прототипи;

- нематеріальні активи на етапі розробки [15]. Об'єднані всі перелічені активи уособлюються в понятті "гудвіл".

На думку Ридзевської О.В., Сало А.В., створений гудвіл стає домінуючим чинником, який покладено в основу ринкової ціни компанії i, подібно до людського капіталу, не може бути визначений калькуляцією об'єктивних вартісних показників [12]. $\Lambda$. Сук і П. Сук у своїх дослідженнях, поряд 3 поняттям гудвілу виділяють його обернену форму - негативний гудвіл. Він виникає, коли покупець при купівлі підприємства платить за нього ціну меншу, ніж сукупна вартість його активів згідно з балансом. Це буває у випадках, коли купується підприємство розташоване у віддаленій місцевості або на території з погано розвиненою інфраструктурою, або за умови вкладення покупцем в придбане підприємство власного капіталу [12; 15$]$.

На нашу думку, науково-дослідні господарства мають дбати про власну ділову репутацію. Піднімати рівень наукової значущості наукових розробок та виводити Україну на міжнародну арену із конкуретноспоможною продукцією.

\section{ВИСНОВКИ}

Аля задоволення потреб менеджменту інформацією для аналізу та внутрішнього контролю операцій із необоротними активами, визначення їх оптимального обсягу та порядку їхнього використання нами уточнено, які саме активи входять до складу необоротних, наведено їх класифікацію.

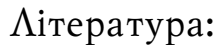

1. Гавриловський О.С., Сташенко Ю.В. Поняття "необоротні активи" в обліковій практиці. Глобальні та національні проблеми економіки. Миколаївський національний університет імені В.О. Сухомлинського. 2017. № 19. С. 498-502. URL: http://global-national.in.ua/archive/192017/96.pdf

2. Гончарук І.В., Браніцький Ю.Ю., Томашук I.B. Основні аспекти ефективного форму- вання і використання ресурсного потенціалу у сільськогосподарських підприємствах (на прикладі Уладово-Аюлинецької АСС ІБК І ЦБ НААН України). Економіка. Фінанси. Менеджмент: актуальні питання науки і практики. 2017. № 10. С. 54-68.

3. Гудзь Н.В., Аенчук П.Н., Романів Р.В. Бухгалтерський облік. 2-е вид., перероб. і доп.: навч. посіб. Київ: "Центр учбової літератури", 2016. 424 c. URL: https://cul.com.ua/preview/buhgu.pdf

4. "Звіт про капітальні інвестиції, вибуття й амортизацію активів" за формою № 2-інвестиції (річна): наказ Аержстату від 21 лип. 2017. № 195 .

5. Капітальні інвестиції за видами активів за 2010-2020 роки. Офіційний сайт Аержстату України. 2020. URL: https://ukrstat.org/uk/ operativ/operativ2013/ibd/ibd_rik/ibd_u/ ki rik u bez.htm

6. Майорова Т.В., Крук В.В., Шевчук Я.В. Капітальні інвестиції: сутність та проблеми реалізації в кризових умовах. Інвестиції: практика та досвід. 2015. № 21. C. 12-16. URL: http:// www.investplan.com.ua/pdf/21 2015/4.pdf

7. Національне положення (стандарт) бухгалтерського обліку 1 "Загальні вимоги до фінансової звітності": наказ М-ва фінансів УКраїни від 07 лют. 2013 р. № 73. URL: https:// zakon.rada.gov.ua/laws/show/z0336-13\#Text

8. Національне положення (стандарт) бухгалтерського обліку 7 "Основні засоби": наказ М-ва фінансів України від 27 квіт. 2000 р. № 92. URL: http://www.visnuk.com.ua/uk/publication/ 100009262-pbo-7-osnovni-zasobi

9. Національне положення (стандарт) бухгалтерського обліку в державному секторі 121 "Основні засоби": наказ М-ва фінансів України від 12 жовт. 2010 р. № 1202. URL: https:// zakon.rada.gov.ua/laws/show/z1017-10\#Text

10. Національне положення (стандарт) бухгалтерського обліку в державному секторі 122 "Нематеріальні активи": наказ М-ва фінансів України від 12 жовт. 2010 р. № 1202.

11. Нова вартість О3 для податкової амортизації у 20 тис. грн: як застосовувати? Вебсайт: Аебет-Кредит. 2020. URL: https://news.dtkt.ua/ taxation/profits-tax/63047

12. Ридзевська О.В., Сало А.В. Поняття гудвілу та характеристика його складових. Наукові праці Кіровоградського національного технічного університету: економічні науки. 2012. № 22 (II). C. 349-352. URL: http:// kntu.kr.ua/doc/zb_22(2)_ekon/stat_20_1/57.pdf

13. Семйон В.С. Актуальні питання обліку необоротних активів в різних літературних 
джерелах. Вісник Житомирського державного технологічного університету: Економічні науки. 2007. № 4 (42). C. 159-166. URL: http:// ven.ztu.edu.ua/article/view/96093

14. Семйон B.С. Поняття необоротних активів, їх класифікація та склад Вісник Житомирського державного технологічного університету: Економічні науки. 2009. № 3 (49). С. $162-166$.

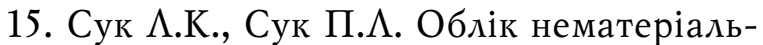
них активів. Бухгалтерія в сільському господарстві. Серпень 2011. № 15-16. С. 45.

16. Хорунжак H.M., Рогожкіна В.В. Понятійна сутність необоротних активів і проблеми iii ідентифікації. Глобальні та національні проблеми економіки. Миколаївський національний університет імені В.О. Сухомлинського. 2017. № 19. C. 554-560. URL: http://global-national.in.ua/archive/19-2017/107.pdf

\section{References:}

1. Havrylovs'kyj, O.S. and Stashenko, Yu.V. (2017), "The concept of "non-current assets" in accounting practice", Hlobal'ni ta natsional'ni problemy ekonomiky, vol. 19, pp. 498-502, available at: http://global-national.in.ua/archive/192017/96.pdf (Accessed 15 May 2021).

2. Honcharuk, I.V. Branits'kyj, Yu.Yu. and Tomashuk, I.V. (2017), "The main aspects of effective formation and use of resource potential in agricultural enterprises (on the example of Vladovo-Dyulinetska DSS IBK and Central Bank of NAAS of Ukraine)", Ekonomika. Finansy. Menedzhment: aktual'ni pytannia nauky i praktyky, vol. 10, pp. 54-68.

3. Hudz', N.V. Denchuk, P.N. and Romaniv, R.V. (2016), Bukhhalters'kyj oblik [Accounting], Tsentr uchbovoi literatury, Kyiv, Ukraine, available at: https://cul.com.ua/preview/buhgu.pdf (Accessed 15 May 2021).

4. State Statistics Service of Ukraine (2017), "Statement of capital investments, disposal and depreciation of assets", available at: https:// zakon.rada.gov.ua/rada/show/v0195832-17\#Text (Accessed 15 May 2021).

5. State Statistics Service of Ukraine (2020), "Capital investments by types of assets for 20102020", available at: https://ukrstat.org/uk/ operativ/operativ2013/ibd/ibd_rik/ibd_u/ ki rik u bez.htm (Accessed 15 May 2021).

6. Majorova, T.V. Kruk, V.V. and Shevchuk, Ya.V. (2015), "Capital investments: essence and problems of realization in crisis conditions", Investytsii: praktyka ta dosvid, vol. 21, pp. 1216, available at: http://www.investplan.com.ua/ pdf/21_2015/4.pdf (Accessed 15 May 2021).
7. Ministry of Finance of Ukraine (2013), "National Accounting Regulation (Standard) 1 "General requirements for financial reporting", available at: https://zakon.rada.gov.ua/laws/ show/z0336-13\#Text (Accessed 15 May 2021).

8. Ministry of Finance of Ukraine (2000), "National Accounting Regulation (Standard) 7 "Fixed Assets", available at: http://www.visnuk.com.ua/uk/publication/100009262-pbo-7osnovni-zasobi (Accessed 15 May 2021).

9. Ministry of Finance of Ukraine (2010), "National Regulation (Standard) of Accounting in the Public Sector 121 "Fixed Assets", available at: https://zakon.rada.gov.ua/laws/show/z101710\#Text (Accessed 15 May 2021).

10. Ministry of Finance of Ukraine (2010), "National Regulation (Standard) of Public Sector Accounting 122 "Intangible Assets", available at: https://zakon.rada.gov.ua/laws/show/z101810\#Text (Accessed 15 May 2021).

11. Debet-Kredyt (2020), "The new cost of equipment for tax depreciation of 20 thousand UAH: how to apply?", available at: https:// news.dtkt.ua/taxation/profits-tax/63047 (Accessed 15 May 2021).

12. Rydzevs'ka, O.V. and Salo, A.B. (2012), "The concept of goodwill and the characteristics of its components", Naukovi pratsi Kirovohrads'koho natsional'noho tekhnichnoho universytetu: ekonomichni nauky, vol. 22 (II), pp. 349352, available at: http://kntu.kr.ua/doc/zb_22(2)_ekon/stat_20_1/57.pdf (Accessed 15 Mā 2021).

13. Semjon, V.S. (2007), "Current issues of accounting for non-current assets in various literature sources", Visnyk Zhytomyrs'koho derzhavnoho tekhnolohichnoho universytetu: Ekonomichni nauky, vol.4 (42), pp. 159-166, available at: http://ven.ztu.edu.ua/article/view/96093 (Accessed 15 May 2021).

14. Semjon, V.S. (2009), "The concept of noncurrent assets, their classification and composition", Visnyk Zhytomyrs'koho derzhavnoho tekhnolohichnoho universytetu: Ekonomichni nauky, vol. 3 (49), pp. 162-166.

15. Suk, L.K. and Suk, P.L. (2011), "Accounting for intangible assets", Bukhhalteriia v sil's'komu hospodarstvi, vol. 15-16, pp. 45.

16. Khorunzhak, N. M. and Rohozhkina, V. V. (2017), "The conceptual essence of non-current assets and the problem of its identification", Hlobal'ni ta natsional'ni problemy ekonomiky, vol. 19, pp. 554-560, available at: http://globalnational.in.ua/archive/19-2017/107.pdf (Accessed 15 May 2021).

Стаття надійшла до редакиї 20.05.2021 p. 